Article

\title{
Mama, Keep Walking for Peace and Justice: Gender Violence and Liberian Mothers' Interreligious Peace Movement
}

\author{
Wonchul Shin (D) \\ Columbia Theological Seminary, Decatur, GA 30030, USA; shinw@ctsnet.edu
}

Received: 5 June 2020; Accepted: 25 June 2020; Published: 30 June 2020

\begin{abstract}
Focusing on the understudied area of women, religion, and peacebuilding, this essay offers the case study of Liberian mothers' actions in the interreligious peace movement to address multiple forms of violence in the midst and aftermath of Liberian civil wars. This essay examines three forms of gender violence and their impact on the lives of Liberian women: (1) sexual violence, (2) forced mobilization of child soldiers, and (3) structural poverty. Afterwards, the essay explores the journey of Liberian mothers to peace and justice and analyzes the role of religion(s) in organizing and sustaining the mothers' interreligious peace movement. Specifically, this essay highlights the concept of motherhood rooted in Pan-African religious traditions as a key moral resource to empower the mothers as peacebuilders and to foster restorative justice in their war-torn nation.
\end{abstract}

Keywords: Liberian women; gender violence; interreligious peacebuilding; motherhood; restorative justice

\section{Introduction}

In the aftermath of the September 11 attacks, there has been a flowering of interest in the intersection of religion, violence, and peacebuilding. New literature focusing on religion as a source of violence and/or peace has emerged across diverse disciplines concerned with the study of religion, such as anthropology, ethics, history, sociology, and theology. However, according to a recent comprehensive literature review of this emerging interdisciplinary field (Appleby et al. 2015), several areas remain little addressed.

One of the understudied areas in this emerging field is the intersection of women, religion, and peacebuilding (Appleby et al. 2015). Although scholarly interest in women's experiences in conflict and violence has grown, it typically portrays women as passive victims of violence (Schnabel and Tabyshalieva 2012); the moral power and agency of women, especially religiously-committed women, in addressing violence and building justice and peace have been neglected. There are a few exceptions that provide robust analyses of the role of women in peacebuilding (Manchanda 2001; Rehn and Sirleaf 2002; Anderlini 2007), but these studies have focused very little on the religious dimension of women's peacebuilding. ${ }^{1}$ In other words, this emerging field has not seriously investigated historical examples of women's creative use of religious-cultural ideologies, symbols, and practices for addressing violence and building justice and peace.

Given the paucity of such interest, this essay offers a concrete case study of an interreligious peace movement organized and practiced by Liberian women, specifically ordinary mothers, in the midst and aftermath of Liberian civil wars in the early twenty-first century. In its first part, this essay

1 There is one exceptional edited volume on the intersection of women, religion, and peacebuilding (Hayward and Marshall 2015). 
critically examines three forms of gender violence which significantly affected the daily lives of Liberian mothers during the Second Civil War: (1) sexual violence, (2) forced mobilization of child soldiers, and (3) structural poverty. In its second part, the essay explores the journey of Liberian mothers toward peace and justice following three chronological phases: before, during, and after the peace talks. Subsequently, it analyzes the role of religions in the Liberian mothers' peace movement. First, drawing on Lisa Schirch's theory of ritual in peacebuilding, I analyze the Liberian mothers' peace movement as interreligious ritual. Second, I highlight the concept of motherhood rooted in Pan-African religious traditions as a key moral resource to empower ordinary mothers as peacebuilders and foster restorative justice in their war-torn society.

\section{Three Forms of Gender Violence in Liberia}

Since freed African Americans founded Liberia in 1847, the country has suffered from social inequality and unequal distribution of wealth between social classes. "Congo People," who are the settlers from the slave boats, and "Americo-Liberians," who have mixed blood and are light skinned, have been privileged over the tribes of Africans who were already living in the Liberian land (Gbowee and Mithers 2011, pp. 7, 8). ${ }^{2}$ In response to the socio-political/economic inequality between social strata, Sergeant Samuel Doe led a bloody coup in 1980 and became "the first non-elite president" of Liberia as a member of the Krahn tribe (Gbowee and Mithers 2011, p. 17).

Though people expected that he would resolve the social problems and bring justice to the indigenous tribes, his government failed to address the social problems. Indeed, the coup was "the precursor of a political reign characterized by corruption, violence and economic decline" (African Women and Peace Support Group 2004, p. 2). ${ }^{3}$ Liberia devolved into a series of armed conflicts. Beginning in December 1989, Charles Taylor's National Patriotic Front of Liberia (henceforth NPFL) waged vicious armed conflict with Doe's government until Taylor was elected president in 1997. This prolonged armed conflict once again resulted in political and economic instability. Liberia plunged into a second civil war from 1999 to 2003. In 1999, Liberians United for Reconciliation and Democracy (henceforth LURD) launched a rebellion against Taylor in northern Liberia. In 2003, a second rebel faction, the Movement for Democracy in Liberia (henceforth MODEL), initiated a rebellion in eastern Liberia. These two rebel groups controlled an estimated 80 percent of the Liberian population. The rebellion killed almost 250,000 people and drove more than a half million into exile (African Women and Peace Support Group 2004). These statistical data represent the tragic social and historical realities which Liberian people faced every day.

In these prolonged civil wars, Liberian women, specifically mothers in their households, experienced at least three forms of gender violence ${ }^{4}$ : (1) sexual violence, (2) forced mobilization of child soldiers, and (2) structural poverty. First, they were exposed to diverse forms of sexual violence. According to the final report of the Republic of Liberia Truth and Reconciliation Commission (2009), women's rights were viciously violated by the following types of wartime sexual violence: "rape, gang rape, multiple rapes, sexual abuse, and sexual slavery, forced pregnancy, forced termination and disembowelment of pregnancy." These types of wartime sexual violence resulted in personal harms, including loss of reproductive and sexual capacity, sexually transmitted diseases, and ostracism and

2 The freed African Americans who settled in Liberia ironically and tragically implemented racial segregation against the African indigenous people-replicating how they had been treated in the U.S. A historical analysis of the rise and augmentation of "the Americo-Liberian class" in Liberia appears in The Quest for Democracy (Liebenow 1987, pp. 47-70).

3 Henceforth, I will use an acronym, AWPSG, for this group.

4 In this essay, gender violence is examined as "an inherent phenomenon of state practices in their continuity and totality, not only during war, but also in relation to patriarchy, racism, sexism, and militarism, practices that lead to the victimization of women during strife and after, in times of peace and in post-conflict/transitional and democratic contexts" (Sanford et al. 2016). Although gender violence does not refer exclusively to violence against women, given the main purpose of this essay, I focus on violence related to the socially-constructed gender roles of Liberian women, specifically mothers. 
victimization because of having been used as a sex slave (Republic of Liberia Truth and Reconciliation Commission 2009). ${ }^{5}$

Second, Liberian mothers suffered because their children were vulnerable to being forced or recruited to join armed groups by Taylor's government or local warlords. Given the Liberian mothers' strong maternal ties to their children, shaped by, and grounded in, Pan-African religious traditions, their children's ordeal also became the mothers' pain. ${ }^{6}$ Child soldiers-the so-called "Taylor's boys" or "Small Boy Units" - were taken away from families and forcibly administered alcohol and drugs until they became "the most merciless killers of all" (Gbowee and Mithers 2011, p. 90). In the documentary film Pray the Devil Back to Hell (2008), one short scene captures the tragic reality of child soldiers in Liberia: an anonymous child soldier aged about nine or ten carries an AK-47 like a toy, smiles, and proudly declares, "I killed three enemy yesterday." It is hard to imagine the extent of the suffering of mothers whose sons or daughters were exploited as child-soldiers. ${ }^{7}$

Third, structural poverty caused violence against people in Liberia. The prolonged armed conflict devastated the economic system of their country. According to the 1999 Human Development Report, national unemployment was as high as 80 percent; 85 percent of the population lived below the poverty line and 55 percent lived in absolute poverty (African Women and Peace Support Group 2004, p. 6). Liberian mothers who lost their husbands and had to take responsibility for their family's livelihood suffered disproportionally from this kind of structural violence. The way in which women typically greeted each other during the civil wars shows their everyday pain in poverty:

We didn't even greet each other with "Good morning" but asked "How was the night?" If the answer was "Praise God," it meant "All right, considering." Praise God: no one shot me or looted my house. We had something to eat. "We're trying" meant "Not so good"—sickness, an empty wallet, a ravenous, wailing infant. (Gbowee and Mithers 2011, p. 86)

\section{The Liberian Mothers' Journey to Peace and Justice}

Liberian women, specifically ordinary mothers, did not resign themselves to the painful experiences of gender violence; rather, they actively addressed the root cause of gender violence-the civil wars. They initiated peace movements to end the civil wars and have faithfully walked the journey to peace and justice in their war-torn nation.

Historically, there are three major Liberian women's peace movements organized by three different NGOs: (1) the Liberian Women's Initiative (henceforth LWI), founded in 1994, (2) the Mano River Union Women's Peace Network (henceforth MARWOPNET), established in 2000, and (3) the Women in Peace Building Network (henceforth WIPNET), founded in March 2003. In this essay, I focus particularly on the women's peace movement organized by WIPNET, "the Liberian Mass Action for Peace" (Theobald 2012, p. 53), given the following factors.

First, the Liberian Mass Action of Peace was an interreligious peace movement. Asatu Bah-Kenneth, a core-leader of WIPNET and a founder of the Liberian Muslim Women for Peace, testified in front of a Christian congregation:

"I was moved and impressed by the Christian Women's Initiative [prayer meetings for national peace]," Asatu said. "God is up. We're all serving the same God. This is not only for the Christian women. I want to promise you all today that I'm going to move it forward

5 Wartime sexual violence is not unique to Liberia or "an African problem." Rather, wartime sexual violence is "a serious problem in most regions of the world." See the United States Institute of Peace's special report on wartime sexual violence (Cohen et al. 2013).

6 I am not arguing for an essentialist view of gender here. Rather, the concept of motherhood in Liberia was shaped and embedded in Pan-African religious traditions. This is discussed further in the latter part of this essay.

7 It is no coincidence that it was the mothers who dedicated themselves to the re-humanization and re-entry of the former child soldiers in the aftermath of the civil wars. This is also discussed later in this essay. 
with the Muslim women. We will come up with something, too, and we will all work together to bring peace in Liberia." (Gbowee and Mithers 2011, p. 125; Emphases mine)

She fulfilled her promise. Christian and Muslim women gathered together to serve the same God and bring peace to their nation.

Second, most participants of this movement were ordinary mothers. Leymah Gbowee, a main leader of WIPNET and a founder of the Christian Women's Peace Initiative (CWI), acknowledges the significant role of two existing women's organizations (MARWOPNET and LWI) in building peace in Liberia, but points out they lacked ordinary women participants:

Both groups [MARWOPNET and LWI] were committed to focusing the world's attention on how the war was affecting women and children and the need for women to play a role in ending war and crafting peace. They did their work at some risk to their lives and were justifiably proud of it. But most of these groups' members were from educated, elite backgrounds. Charles Taylor, who invited some of them to participate in social events and official diners, referred to them as "the eminent women of Liberia." They were also a bit insular and protective of their territory. (Gbowee and Mithers 2011, p. 115; Emphasis mine)

Compared to these groups' demographic composition, WIPNET put an emphasis on a peace movement organized and practiced at the grassroots level. Ordinary women facing daily challenges of gender violence- "market women," "displaced women from the camps," and "wom[e]n [who have] used a curtain for a hair tie"- -gathered together and rallied for peace and restoration (Gbowee and Mithers, p. 137). Among the core leaders of WIPNET were thirteen women who did not have the privilege of an education. One of them was Grace Jarsor, "a very poor and struggling young mother who belonged to a Monrovia Lutheran church and craved something more for her life" (Gbowee and Mithers, p. 124).

In short, the interreligious peace movement organized and practiced by WIPNET included many ordinary women and proceeded in three phases: (1) before the peace talks in Accra, Ghana, (2) during the peace talks, and (3) after the peace talks and the peace agreement. First, during the armed conflicts between Taylor's government and local rebels (LURD and MODEL), WIPNET initiated "the Peace Outreach Project" to mobilize local women to participate in the protest for peace and organized the first street march in Monrovia (the capital city of Liberia) in December 2002 (Gbowee and Mithers 2011, p. 129). About two hundred Christian and Muslim women participated in the first protest. Then, Gbowee announced a vision statement written by Jarsor: "we envision peace. A peaceful coexistence that fosters equality, collective ownership and full participation of particularly women in all decision-making processes for conflict prevention, promotion of human security and socioeconomic development" (Gbowee and Mithers 2011, p. 129.).

After the first protest, in April 2003, WIPNET initiated a prolonged nonviolent protest called the Mass Action for Peace, in order to (1) express their sorrow and frustration about the armed conflicts, (2) challenge Taylor's government, and (3) bring peace and justice to Liberia. Every morning, wearing white T-shirts with the WIPNET logo and white hair ties and holding posters and placards, more than two thousand ordinary women of different religious traditions (specifically Christianity and Islam) and different social/ethnic backgrounds gathered in the empty field near the fish market in Monrovia. There they sat, danced, sang, wept, prayed, and fasted for peace and justice (Theobald 2012, p. 53; Gbowee and Mithers 2011, p. 136). They also declared their intention to "set forth a three-point program": (1) "an immediate ceasefire," (2) "dialogue among the opposing parties [peace talks]," and (3) "international monitoring of the ceasefire" (African Women and Peace Support Group 2004, p. 46).

The public attention to this protest grew, and these protesters finally met Taylor on April 23, 2003. Hundreds of women sat down in front of Taylor's Executive Mansion and prayed for Gbowee while she delivered to the dictator their statement urging peace talks with rebels (Theobald 2012, p. 53; Gbowee and Mithers 2011, pp. 140-41). At the same time, the women also pressured the LURD leaders to hold peace talks with Taylor and other local rebels. When the LURD leaders had a 
meeting with representatives from the Liberian Council of Churches in Sierra Leone, some WIPNET leaders went along and mobilized Liberian women from a refugee camp to protest at the meeting (Gbowee and Mithers 2011, p. 143). Taylor and local rebels finally agreed to have the peace talks in Ghana in June 2003.

The news of the peace talks in Ghana between Taylor and the rebels brought joy to the women, but the joy soon turned to disappointment. The peace talks began on 3 June 2003, but it quickly became clear that Taylor and the local warlords were only interested in consolidating their own political and economic power, which resulted in there being no peace agreement until the end of June. From the beginning of the peace talks, WIPNET sent leaders and local women to Ghana and mobilized Liberian women from a refugee camp there. Throughout the peace talks, hundreds of women sat in front of a hotel where the peace talks were being held and wept, sang, and chanted "WE WANT PEACE" (Gbowee and Mithers 2011, p. 155).

Meanwhile, Taylor was abruptly indicted by the international criminal court in Sierra Leone and went back to Ghana. His return prompted another full-scale armed conflict in Liberia. Amidst this desperate situation, in July 2003, the leaders of WIPNET decided to seize the peace hall until a peace agreement was established. More than two hundred women sat down with their arms looped together. Gbowee handed a note to General Abubakar, a former president of Nigeria and a facilitator of the peace talks: "We are holding these delegates, especially the Liberians, hostage. They will feel the pain of what our people are feeling at home" (Gbowee and Mithers 2011, p. 161). After seizing the peace hall, Gbowee told the world of the Liberian women's firm resolution to keep walking toward peace. She declared:

What we've done today is send out a signal to the world that we, the Liberian women in Ghana, at this conference, we are fed up with the war, and we are doing this to tell the world we are tired of the killing of our people. We can do it again —and we will do it again! (Gbowee and Mithers 2011, p. 163)

Even though the civil war did not end on that day, under pressure from the Liberian women, Taylor's government, LURD, MODEL, and other local rebels finally signed the Accra Comprehensive Peace Agreement on August 18 (Gbowee and Mithers 2011, p. 164). The Liberian women protesting outside the negotiation hall had played a decisive role in catalyzing the peace agreement. ${ }^{8}$

Even after the peace agreement, the Liberian women of WIPNET did not stop their journey toward achieving peace and justice. As Gbowee points out in her memoir, for them peace is not "a moment," but "a very long process" (Gbowee and Mithers 2011, p. 168). Unless traumatized communities, including both victims and victimizers in the civil wars, are healed, there can be no peace. For this process of peacebuilding in the post-conflict phase, WIPNET collaborated with LWI and the UN mission in Liberia (henceforth UNMIL). They held a conference that helped ordinary women understand what the peace agreement meant for them (Gbowee and Mithers 2011, p. 168). They also contributed to the process of "DDR": disarmament, demobilization, and reintegration (Gbowee and Mithers 2011, p. 169).

In particular, WIPNET played a critical role in the process of DDR for the former child soldiers. The initial process of DDR led by UNMIL had failed, since this organization did not acknowledge and appreciate the value of insiders' knowledge and wisdom to take care of their broken communities. Liberian women are experts at preventing conflict and building peace, since they, as mothers, already play the role of mediator in their homes and communities (Gbowee and Mithers 2011, p. 171). WIPNET highlighted such ordinary mothers' wisdom and used it to disarm the child soldiers and to reintegrate (physically, psychologically, and morally) wounded children into their communities.

8 Some Liberian women of MARWOPNET who were present as delegates at the peace talks in Ghana also played a critical mediation role among the various factions in the peace talks. This organization was selected as one of six recipients of the United Nations Prize in the Field of Human Rights (African Women and Peace Support Group 2004, pp. 51-52). 
In addition, in order to secure political stability and women's empowerment, WIPNET launched a "grassroots campaign to register women to vote": WIPNET women visited ten communities and met and talked with indigenous women, market women, and poor women about "the power of the democratic voting process" (Lederach and Lederach 2010, p. 33; Gbowee and Mithers 2011, pp. 182-83). Many women subsequently registered to vote, increasing women's total share of the electorate to approximately 50 percent: this eventually contributed to electing the first female president, Ellen Johnson-Sirleaf, in Liberia (Theobald 2012, p. 54).

The war was over. A woman president had been elected. However, this did not mean the end of Liberian women's journey to peace and justice. WIPNET changed its name to WIPSEN, the Women in Peace and Security Network, and to this day the Liberian women of WIPSEN continue their journey of building peace and healing the wounds of their children and communities (Gbowee and Mithers 2011, pp. 189, 230).

\section{The Role of Religion(s) in the Liberian Women's Peace Movement}

Though there are a few scholarly works on the Liberian women's peace movement (African Women and Peace Support Group 2004; Theobald 2012; Adebajo 2014), they have paid very little attention to the role of religion(s) in the movement. Given this understudied area, in what follows I analyze the Liberian women's nonviolent demonstrations organized by WIPNET-the Mass Action for Peace-in terms of interreligious ritual. In her book Ritual and Symbol in Peacebuilding, Lisa Schirch defines ritual as using "symbolic actions to communicate a forming or transforming message in a unique social space" (Schirch 2005, p. 17). Actions in ritual are enacted through "symbols, senses, and emotion rather than words or rational thought" (Schirch 2005, p. 17). Some rituals may reinforce already established worldviews, identities, and social relationships, but other rituals may transform them (Schirch 2005, p. 17). Finally, ritual takes place in a unique space, distinguished from normal life (Schirch 2005, p. 17). Schirch then delineates types of ritual: rituals can be "religious or secular, traditional or improvised, formal or informal, forming or transforming, and destructive or constructive (Schirch 2005, pp. 18-19). Based on these definitions, she identifies indispensable components of rituals: (1) a "special and unique space"; (2) "actions that symbolically do something"; (3) "emotional and sensual communication"; and (4) "playing a role in socializing and/or transforming in community life" (Schirch 2005, p. 28).

In her ritual scheme, the Mass Action for Peace (the nonviolent demonstrations in the fish market) fits the category of ritual. First, it took place in the fish market. Clearly, this place symbolizes the "normal" and "everyday" life of the mothers. However, they intentionally chose this normal place to correlate their everyday practices—such as selling something to provide for their families—and practices of peacebuidling and political resistance against the government and local rebels. As they engaged in political activities every day, this normal space was transformed into a unique space for the mothers in political resistance.

Second, their actions — sitting, singing, chanting, dancing, weeping, praying, and fasting — symbolically represent the harsh social realities of violence which they faced and their desperate need for peace and justice in their nation. They gathered together in the fish market and sang a song:

We want peace, no more war.

Our children are dying—we want peace.

We are tired [of] suffering-we want peace.

We are tired [of] running—we want peace. (Gbowee and Mithers 2011, p. 140)

Along with their chanting and singing, the women's bold action of blocking the peace hall embodied and communicated their emotions, such as anger and frustration, and their unyielding commitment to peace and justice. 
Third, they expressed emotions such as grief, anger, frustration, and also joy and hope. For example, the documentary film Pray the Devil Back to Hell shows that women who went to Ghana during the peace talks wept and sang together when they heard that their families were at risk due to the armed conflict between Taylor's government and LURD.

Lastly, by participating in the protest, women's identity as mothers was transformed from being nobodies to being active agents of peacebuilding. Before the protest, they were merely "market women," but they became the mothers of the nation by building peace and justice in it. (The dynamic relation between the concept of motherhood, women's identity, and their moral agency is discussed in the next part.) In addition, the nonviolent protest itself challenged the wider society, specifically Taylor's government and local warlords. Their symbolic actions raised a crucial awareness of the need for peace and justice in Liberia and eventually played an important role in pressuring Taylor and the rebels to sit down at the negotiation table to hash out the peace agreement, along with other social factors, such as Taylor's indictment.

Given these components of ritual, the Mass Action for Peace was an example of a specifically interreligious ritual. As we found earlier, participants in this movement were Christian and Muslim women, so they drew on their Christian and Muslim practices for the formats and contents of the demonstrations. They always started the protest with prayers in each religious tradition:

The Lord is my shepherd; I shall not want ...

In the name of Allah, the Beneficent, the Merciful

Praise be to Allah, Lord of the Worlds ... (Gbowee and Mithers 2011, p. 138)

At the beginning of the protest, they invoked God's presence: they believed that they served the same God and sang both Christian hymns and Muslim songs. They then prayed again for God's guidance, protection, and strength in order to persevere until they brought about peace:

I will life up mine eyes unto the hills, from whence cometh my help

My help cometh from the Lord, which made heaven and earth ...

In the name of Allah, the Beneficent, the Merciful ...

Guide us on a straight path,

The path of those whom Thou has favored;

Not of those who earn Thine anger nor of those who go astray. (Gbowee and Mithers 2011, p. 139)

In addition, the women in the protest re-appropriated the religious symbolism embedded in their sacred texts. For example, they wore white T-shirts with the WIPNET logo and white hair ties, which symbolize their dedication to the salvation of their people and nation, much as the heroic Queen Esther in the Book of Esther put on sackcloth and ashes and stood up against injustice and saved her people. Taylor banned any type of protest against his government, so organizing and participating in the demonstrations could be dangerous. However, just as Esther risked her life for her people, so too these Liberian women demonstrated their steadfast commitment to peace and justice through biblical symbolism. In short, religions - both Christianity and Islam-played a significant role in shaping the distinctive character of the Mass Action for Peace as an interreligious ritual.

Along with Christianity and Islam, African traditional religion played a crucial role in the process of reshaping the Liberian women's identity and reconstructing their moral agency. Specifically, WIPNET actively used the concept of motherhood rooted in Pan-African religious traditions for this process. As a "spiritual grammar and ethic" rooted in Pan-African religious cultures, the concept of motherhood served the role of what Dianne M. Diakite calls a "silent [religious] cultural partner" in the Liberian women's peace movement (Diakite 2013, p. 75). 
Some African scholars, such as Oyeronke Oyewumi, argue that the concept of motherhood has served as the chief foundation of social/family structures, identity, ideology, and ethics for Africans. Oyewumi suggests an alternative model of solidarity based on an African ideology and ideal. She calls it "mothernity" and roots it in the Yoruba tradition (Oyewumi 2003, pp. 4, 11). She contends that "there is no sisterhood without motherhood" in many African societies, and argues that the concept of motherhood is "the most important source and model of solidarity" by examining the concept of omoya in the Yoruba tradition, which means "my mother's child or children" (in English) (Oyewumi 2003, p. 13; Diakite 2013, p. 64). She observes:

The category of omoya transcends gender; sometimes it is used to refer to an individual, but what is encapsulates is the collectivity. It functions to locate the individual within a socially recognized grouping and underscores the significance of mother-child ties in delineating and anchoring a child's place in the family ... Thus, the most important shared experience that omoya recalls and builds on is the fact that the group of siblings shared the womb of the mother. (Oyewumi 2003, p. 12)

From this examination of the concept of omoya, we note that Africans' collective identity is most deeply shaped by their maternal ties. In addition, omoya symbolically emblematizes "unconditional love, togetherness, unity, solidarity, and loyalty" (Oyewumi 2003, p. 12). In African societies, mothers are understood as those who have "agency and power" to shape the collective identity and embody certain ideals in their nurturing of children and community: "being a mother is perceived as an attractive and desirable goal to achieve" in African societies (Oyewumi 2003, pp. 5, 13).

Ifi Amadiume also tries to discover "the matriarchal roots of Africa," which European studies of African society have overlooked due to their preoccupation with the patriarchal system (Amadiume 1997, p. 29). She closely examines social/family structures, religious traditions, and moral systems in the Nnobi Igbo society, in Africa (particularly Nigeria). She argues:

This ideology of gender had its basis in the binary opposition between the mkpuke, the female-focused matricentric unit and the obi, the male-focused ancestral house. The structure of relationship, in the Levi-Straussian sense, between these two paradigmatical gender structures, reflected in the wider social organization and politics of Nnobi ... They formed interrelating systems representing different values such as compassion/love/peace in the ideology of umunne, the spirit of common motherhood, and competitiveness/masculinism/valour/force/violence in the ideology of umunna, common fatherhood. Social subjects thus had access to more than one moral system. (Amadiume 1997, p. 18)

She highlights the matricentric foundation of social structures and ideology, which she distinguishes from the male-focused social organization and ideology. This matricentric unit and ideology is based on a religious belief in "the whole of Nnobi [being] bound [together] as children of a common mother-the goddess Idemili, the deity worshipped by all Nnobi" (Amadiume 1997, p. 18). She then argues that the matricentric foundation formulates "alternative moral systems [characterized by love and compassion] available to social subjects, both male and female, in the course of social relations" (Amadiume 1997, p. 40).

Given the importance of the matricentric foundation rooted in Pan-African religious traditions, WIPNET drew on this concept of motherhood to articulate ordinary women's moral agency and empower them as active agents of peacebuilding. Before starting the Mass Action for Peace, WIPNET implemented women's empowerment, through a project called "Being a Woman" (Gbowee and Mithers 2011, p. 117). In this project, the leaders of WIPNET articulated the moral agency of ordinary women by re-shaping their identity as mothers. Their conversations went like this:

"Who are you as a woman?"

"I'm nobody ... a mother. A children-mother." 
"What are the things you do as a mother? Do you work to make money for your children?

“Yessss ..."

“Then you are also a provider."

(A smile.) "Yes. I am a provider."

“Do you work in your church?"

"Yes ..."

"So you are also a leader. Do you help to solve problems in the church? In your community?"

"Yes, I do."

"Aaah. So you are a peacemaker."

"I am! I am a peacemaker!" (Gbowee and Mithers 2011, pp. 117-18; Emphasis mine)

As this conversation shows, ordinary women previously regarded themselves as nobody, having no agency and power. However, when the WIPNET helped them to discover their own power in nurturing their children and communities, their identity as mothers was transformed from being nobodies to being providers, leaders, and peacemakers. In other words, their re-shaped identity served as a moral resource to construct their moral agency and actively enact the ideals of motherhood-unconditional love, compassion, and solidarity-into actual practices of peacebuilding as another form of nurturing their children and communities.

There is a lot of evidence suggesting that ordinary women who participated in the peace movement have a clear sense of their identity as morally empowered mothers. We can find an example of this in the position statement of WIPNET delivered to Charles Taylor. As a representative, Gbowee declared:

With this message: that the women of Liberia, including the IDPs [internally displaced persons], we are tired of war... We are now taking this stand, to secure the future of our children. Because we believe, as custodians of society, tomorrow our children will ask us, 'Mama, what was your role during the crisis?' (Gbowee and Mithers 2011, p. 141; Emphasis mine)

They regarded themselves as mothers whose children were exploited as child soldiers, raped, and impoverished during the prolonged civil wars. Their children, their communities, and their nation were at stake, so they took the action of co-mothering wounded children, communities, and the nation.

The Liberian people also recognized the women as virtuous mothers and acknowledged their moral virtues, namely courage, endurance, and compassion. Ordinary people, including businessmen and even soldiers and government officers funded the Liberian mothers' Mass Action for Peace. These supporters said to the women: "Thank you, mothers," "Our future depends on you" (Gbowee and Mithers 2011, p. 149; Emphasis mine). Even the leaders of LURD acknowledged that the women's moral power influenced their decision to go to the peace talks in Ghana. They told women who protested in Sierra Leone: "Well, mothers, because of you, we will go [to the peace talks in Ghana]" (Gbowee and Mithers 2011, p. 143; Emphasis mine).

Given women's collective identity as mothers and the public recognition of their moral power, we recognize that the concept of motherhood, which is deeply embedded in Pan-African religious traditions, was used to develop ordinary women's moral agency. Through their re-shaped identity, Liberian mothers successfully redressed the root cause of gendered violence: the vicious armed conflict. They testified that they are the mothers of their children, the mothers of their communities, and the mothers of their nation.

Along with this moral empowerment, the religious concept of motherhood provided Liberian women with the moral framework for fostering restorative justice. In other words, the matricentric 
foundation enabled them to envisage the ideals of restorative justice (rather than conventional concepts of justice such as retributive justice) and put the ideals into actual practice, specifically their practices of DDR (disarmament, demobilization, and reintegration) for the former child soldiers.

Geoff Broughton introduces a common understanding of restorative justice, one that "encompasses the theory and practice of just-making in which the relationships of people and communities are integral to "make things right'" (Broughton 2009, p. 304). He acknowledges that there is no single definition of restorative justice, but he offers two principles as a start:

First, justice requires that we work to heal victims, offenders and communities that have been injured by crime. Second, victims, offenders and communities should have the opportunity for active involvement in the justice process as early and as fully as possible. (Broughton 2009, p. 304)

The first principle refers to the goal of restorative justice: healing wounds not only of victims, but also those of offenders and communities. This goal is different from the central concern of the conventional concepts of justice: fairness, retribution, and punishment.

The second principle mentions the collaboration among three parties: specifically, communities are not aloof spectators or bystanders, but active participants in the process of healing wounds caused by crime. The conventional models of justice, such as retributive justice, do not allow room for victims and communities to participate in the just-making process, so this principle is a distinctive aspect of restorative justice.

Howard Zehr affirms these two principles. He defines restorative justice as follows:

Crime is a violation of people and relationships. It creates obligations to make things right. Justice involves the victim, the offender, and the community in a search for solutions which promote repair, reconciliation, and reassurance. (Zehr 1990, p. 181)

Instead of defining justice as retribution, we will define justice as restoration. If crime is injury, justice will repair injuries and promote healing. Acts of restoration-not further harm-will counterbalance the harm of crime. We cannot guarantee full recovery, of course, but true justice would aim to provide a context in which the process can begin (Zehr 1990, p. 186; Emphasis mine)

Here, he clearly defines that the ultimate end of restorative justice is restoration, which entails the repair of the broken relationships and the healing of wounds. He also stresses that all parties-the victim, the offender, and the community - have to work in tandem in a search for restoration.

By suggesting restorative justice as an alternative to retributive justice, Theophus Smith also argues:

Restorative justice ... uses the framework of compensation and punishment as the means to a larger goal of restoring damaged relationships in the community where offenses occur by repairing where practicable the relationship between victims and offenders, and repairing as well the broader civic and social relationships that have been fractured by the offense.

\section{(Smith 2005, p. 49)}

He claims that the central concern of restorative justice goes beyond mere compensation or punishment: its larger goal is restoration of broken relationships. He then expands the boundary of broken relationships, which restorative justice aims to mend, from the relationship between the victim and the offender to "the broader civic and social relationships" (Smith 2005, p. 49). More importantly, he explains the restoration of broken relationships in terms of the restoration of humanity:

“[W]hy we 'can't get no satisfaction' from retributive justice."” Satisfaction eludes practitioners of retributive justice because such justice remains captive to the shame-rage cycle of injury-and-retaliation. What really satisfy, on the contrary, are procedures [of restorative justice] that enable us to resolve our shame in processes that simultaneously restore our humanity [the human dignity and worth]. (Smith 2005, p. 48) 
Given his emphasis on the restoration of humanity, retributive justice is not enough to address this issue: the more retributive justice is the goal, the more people are trapped in the endless cycle of vengeance, and the more their humanity is lost. However, practices of restorative justice help us to restore our human dignity and worth: they entail the re-humanization of both victims and offenders.

To sum up these three scholars' arguments concerning restorative justice, we can identify a working definition of restorative justice for this essay: restorative justice enables victims, offenders, and communities to work together to achieve the ultimate goal of restoration, specifically of restoring the humanity of all parties. Within this framework of restorative justice, the Liberian mothers were both victims and a community. Yet they did not remain in the seat of the victim or spectator. Instead, they actively engaged in enacting principles/ideals of restorative justice through their peace movement.

Before joining WIPNET, Gbowee was devoted to her volunteer work of healing the psychological and moral injuries of ex-child soldiers. However, after serving as a key leader of this organization, she discovered that peacebuilding is a primary practice of restoration in her country. She said:

WIPNET brought everything together for me: You can't cure trauma when violence is ongoing, so the primary effort must be working for peace. You can't negotiate a lasting peace without bringing women into the effort, but women can't become peacemakers without releasing the pain that keeps them from feeling their own strength. Emotional release isn't enough in itself to create change, but WIPNET channeled that new energy into political action. This was a way to do it all. (Gbowee and Mithers 2011, p. 114)

Following her vision, WIPNET implemented the women's empowerment project: ordinary women found a moral agency by discovering their own power and wisdom in their motherhood. This organization also created a space of religious ritual — the protest at the fish market—and women expressed their pain, anger, and frustration by weeping, singing, and praying together. Simultaneously, WIPNET provided women with various channels - the nonviolent demonstrations, the DDR, the voter registration, etc.- through which to exert their moral power and wisdom in public. The entire process aimed to heal the wounds of their children and their communities and to bring peace and restoration to their nation. Indeed, their peace movement was a concrete practice of restorative justice.

The highlight of the Liberian women's peace movement as a practice of restorative justice was their involvement in the process of DDR for the former combatants, including child soldiers. According to the conventional model of retributive justice, ex-combatants, who caused harm to civilians, and even child soldiers (Taylor's Boys), deserved to be punished. When Gbowee helped ex-child soldiers, some people condemned her action. They said, "You're wasting your time here! The boys who victimized us during the war are now in the army! In the police force! You'd better keep coming back to heal us, because when you leave they just move in and do it to us all over again" (Gbowee and Mithers 2011, p. 104). This remark shows the damaged relationships between the victims, the offenders, and the ongoing hatred and distrust in Liberia.

However, Liberian women as mothers embraced the ex-combatants and child-soldiers and helped them to restore their humanity in the process of DDR. Gbowee explained:

'We engaged in real relationships with the child soldiers. We saw them not as perpetrators of violence, but as our sons and daughters.' They ate food together, laughed and cried together. 'We had to rehumanise them in their powerlessness. We had to take away not only their guns but also their vulnerability. We had to give them a new kind of power.' In the presence of their mothers, the children no longer found power in their guns, but in their relationship. 'We took away their fear and gave them a new kind of boldness through love.' (Lederach and Lederach 2010, p. 32; Emphasis mine)

The Liberian mothers nurtured child soldiers to help them find their dignity and worth in their peaceful relationship with others, not in their weapons. They facilitated their reintegration into the community. In this restoration of the child soldiers' humanity, the concept of motherhood, characterized 
by the ideals of compassion and solidarity, served as a moral resource to envisage an alternative model of justice: restorative justice.

The mothers did not have any legal responsibility to help child soldiers. However, they were committed to restoring their humanity-the vision of restorative justice-since they identified themselves as the mothers of child soldiers: "We [Liberian women] saw them [child soldiers] not as perpetrators of violence, but as our sons and daughters" (Lederach and Lederach 2010, p. 32). As indicated earlier, the spirit of common motherhood (the ideology of umunne) in the Nnobi religious tradition represents the moral system of values such as compassion, love, and peace (Amadiume 1997, p. 18). This moral system of motherhood became the foundational soil in which Liberian women committed themselves to pursue the ideal end of restorative justice: the restoration of the child soldiers' humanity.

\section{Conclusions}

Throughout this essay, we have seen the moral courage, power, and wisdom of ordinary women in Liberia on the ground. They did not resign themselves to the social and historical context of the civil wars and human right abuses. The mothers of children, communities, and the nation created a space in which to shout "We Want Peace, No More War," wherever they go. They faithfully walked through the journey to peace and restoration in their country. And they will continue to make this journey until the wounds of their nation are fully healed.

This paper was intended to uncover the unheard voices of ordinary women whose stories had been marginalized. I acknowledge the limitations of this essay in light of this intention. It was challenging to find written testimonies or narratives of ordinary Liberian women who actively participated in the peace movement. The book Liberian Women Peacemakers, written by the African Women and Peace Support Group, contained sixteen women's testimonies, but most of them were well educated and belonged to the middle-upper class, as lawyers, chief justices, senators, etc. I therefore mainly drew on testimonies and stories in Gbowee's memoir, which show her work with ordinary women. More qualitative data on ordinary women's emotions, thoughts, and stories could strengthen this essay's commitment and corroborate my analysis of the role of religions, specifically the matricentric foundation of the Liberian mothers' peace movement.

Funding: This research received no external funding.

Conflicts of Interest: The author declares no conflict of interest.

\section{References}

Adebajo, Adekeye, ed. 2014. Africa's Peacemakers: Nobel Peace Laureates of African Descent. London: Zed Books. African Women and Peace Support Group. 2004. Liberian Women Peacemakers: Fighting for the Right to be Seen, Heard, and Counted. Trenton: Africa World Press.

Amadiume, Ifi. 1997. Re-Inventing Africa: Matriarchy, Religion, and Culture. London: Zed Books.

Anderlini, Sanam. 2007. Women Building Peace: What They Do, Why It Matters. Boulder: Lynne Rienner Publishers.

Appleby, R. Scott, David Little, and Atalia Omer, eds. 2015. The Oxford Handbook of Religion, Conflict, and Peacebuilding. New York: Oxford University Press.

Broughton, Geoff. 2009. Restorative Justice: Opportunities for Christian Engagement. International Journal of Public Theology 3: 299-318. [CrossRef]

Cohen, Dara Kay, Amelia Hoover Green, and Elisabeth Jean Wood. 2013. Wartime Sexual Violence. Special Report 323. Washington: United States Institute of Peace, Available online: https://www.usip.org/sites/default/files/ resources/SR323.pdf (accessed on 15 May 2020).

Diakite, Dianne M. 2013. 'Matricentric' Foundations of Africana Women's Religious Practices of Peacebuilding, Sustainability, and Social Change. Bulletin of Ecumenical Theology 25: 61-79.

Gbowee, Leymah, and Carol Mithers. 2011. Mighty Be Our Powers: How Sisterhood, Prayer, and Sex Changed a Nation at War. New York: Beast Books. 
Hayward, Susan, and Katherine Marshall, eds. 2015. Women, Religion, and Peacebuilding: Illuminating the Unseen. Washington: United States Institute of Peace.

Lederach, John Paul, and Angela Jill Lederach. 2010. When Blood and Bones Cry Out: Journeys through the Soundscape of Healing and Reconciliation. New York: Oxford University Press.

Liebenow, J. Gus. 1987. Liberia: The Quest for Democracy. Bloomington: Indiana University Press.

Manchanda, Rita, ed. 2001. Women, War, and Peace in South Asia: Beyond Victimhood to Agency. New Delhi: Sage Publications.

Oyewumi, Oyeronke. 2003. African Women and Feminism: Reflecting on the Politics of Sisterhood. Trenton: Africa World Press.

Pray the Devil Back to Hell. 2008. Directed by Gini Reticker. New York: Folk Films.

Rehn, Elisabeth, and Ellen Johson Sirleaf. 2002. Women, War and Peace: The Independent Experts' Assessment on the Impact of Armed Conflict on Women and Women's Role in Peacebuilding. New York: United Nations Development Fund for Women.

Republic of Liberia Truth and Reconciliation Commission. 2009. Volume Three: Appendices Title I: Women and the Conflict. Available online: http://www.trcofliberia.org/resources/reports/final/volume-three-1_layout-1.pdf (accessed on 27 April 2020).

Sanford, Victoria, Katerina Stefatos, and Cecilia M. Salvi, eds. 2016. Gender Violence in Peace and War: States of Complicity. New Brunswick: Rutgers University Press.

Schirch, Lisa. 2005. Ritual and Symbol in Peacebuilding. Bloomfield: Kumarian Press.

Schnabel, Albrecht, and Anna Tabyshalieva, eds. 2012. Defying Victimhood: Women and Post-conflict Peacebuilding. Tokyo: United Nations University Press.

Smith, Theophus. 2005. Vengeance Is Never Enough: Alternative Visions of Justice. In Roads to Reconciliation: Conflict and Dialogue in the Twenty-First Century. Edited by Amy Benson Brown and Karen M. Poremski. New York: M.E. Sharpe, pp. 35-51.

Theobald, Anne. 2012. The Role of Women in Making and Building Peace in Liberia: Gender Sensitivity versus Masculinity. Stuttgart: Ididem-Verlag.

Zehr, Howard. 1990. Changing Lenses: A New Focus for Crime and Justice. Scottdale: Herald Press.

(C) 2020 by the author. Licensee MDPI, Basel, Switzerland. This article is an open access article distributed under the terms and conditions of the Creative Commons Attribution (CC BY) license (http://creativecommons.org/licenses/by/4.0/). 